\title{
PENICILLIN IN OIL-WAX MIXTURES
}

\author{
BY \\ J. R. MAY \\ From the Laboratories of the Wright-Fleming Institute of Microbiology, \\ St. Mary's Hospital, Paddington, London
}

\section{Introduction}

One of the main disadvantages of penicillin as a chemotherapeutic agent is that the kidney is able to eliminate it from the blood in a relatively short time, making it necessary that injections be repeated fairly frequently in order to maintain a therapeutic blood level for a long period. This is, of course, most undesirable from the patient's point of view and many workers have attempted to find means whereby the number of injections per twenty-four hours could be lessened. The most promising method so far developed to this end is that introduced by Romansky and Rittman (1944), who incorporated the penicillin in a mixture of peanutoil (arachis oil) and beeswax. This mixture had the property, when injected into the body, of giving a slow release of penicillin, with consequent prolongation of detectable blood levels and therefore a reduction of the number of injections required. Romansky concluded that the optimum results were obtained with a mixture containing 4.8 per cent. beeswax in arachis oil with a maximum penicillin concentration of $300,000 \mathrm{u} / \mathrm{ml}$., the penicillin having a potency of not less than $1,000 \mathrm{u} / \mathrm{mg}$.

However, the use of Romansky's preparation is not without difficulties, for at room temperature this mixture is solid and it requires heating to a temperature between $40^{\circ}$ and $50^{\circ} \mathrm{C}$. to be melted. Even then the bore of the needle needed for injecting it is large and somewhat uncomfortable for the patient. The difficulty of heating the preparation before use is easily overcome in hospital practice where all facilities are present, but the position is often quite different for the general practitioner attending a patient in his own home.

The difficulties inherent in the use of Romansky's preparation led to the search for other preparations which would give a similar prolongation of penicillin blood levels but which would be fluid at room temperature and would pass through a relatively fine-bore needle. Of such preparations the ones giving the most encouraging results to date have been mixtures of beeswax in ethyl oleate, which are fluid at room temperature and can be injected through a finer-bore needle than that required for Romansky's preparation. It has been said, however, that the beeswax-ethyl-oleate mixtures do not give such prolonged penicillin blood levels as beeswax and arachis oil, and the object of the present investigation, carried out on behalf of the Ministry of Health, has been to compare the penicillin blood levels obtained with beeswax mixed with ethyl oleate on the one hand and arachis oil on the other.

\section{The Present Investigation}

Preparations.-The penicillin used in aqueous solution for the control experiments was the standard sodium salt prepared by Glaxo Laboratories, having a potency of 1,200 to $1,400 \mathrm{u} / \mathrm{mg}$.

The majority of the beeswax in arachis oil preparations were the ones in current use in the Department for Venereal Diseases at St. Mary's Hospital, prepared by Glaxo Laboratories and Burroughs Wellcome Limited. The composition varied slightly in different brands, the beeswax content being 4.5 per cent. in some cases and 4.8 per cent. in others, while the penicillin content varied from 125,000 to $300,000 \mathrm{u} / \mathrm{ml}$.

In addition to these, two preparations made by Imperial Chemical Industries Limited were also tested. Both were fluid at room temperature. One (No. PD/RS 465/47) contained 1 per cent. beeswax in arachis oil with 300,000 units of pure penicillin 2(G) per ml., while the other (No. 20622) contained 4.5 per cent. beeswax and 125,000 units of commercial penicillin per $\mathrm{ml}$. The modifications in the latter over Romansky's preparation, making it fluid at room temperature, are not stated.

Beeswax and ethyl oleate mixtures were prepared by the following firms specially for the investigation: British Drug Houses Limited, and Boots Pure Drug Company Limited. One mixture containing 125,000 units of penicillin per ml. and 4 per cent. beeswax was the standard preparation marketed by Boots Pure Drug Company. The percentages of beeswax in the ethyl oleate mixtures were 4 per cent., 4.8 per cent., and 
6 per cent. The penicillin concentrations varied between 50,000 and $300,000 \mathrm{u} / \mathrm{ml}$.

Subjects.-Most of the subjects on whom the investigations were carried out were attending the Venereal Diseases Department of St. Mary's Hospital. Some were also taken from the general wards of the hospital, no cases with any suspicion of renal disease being accepted. A few experiments were also performed on normal healthy adults.

Both males and females were used in these experiments, the former preponderating, since in the venereal disease clinic they were found to be more co-operative than the latter.

- The test subjects were divided into two groups: (a) cases confined to bed; and (b) ambulant cases. In the former group it was possible to obtain blood specimens at much more frequent intervals than in the latter, owing to the difficulty of out patients being unable to attend more than once or twice a day. In the majority of the ambulant cases, therefore, the blood-level estimations were limited to one at twenty-four hours after administration, but sometimes an earlier estimation was possible.

Penicillin Estimations.-The titrations of penicillin in the serum specimens were all carried out by the method described by Fleming and Smith (1947), using a streptococcus as the test organism and a glucose-phenol redserum water medium as the diluent. It should be noted that inhibition of this particular streptococcus by undiluted serum indicates a penicillin concentration of $0.03 \mathrm{u} / \mathrm{ml}$. Though smaller concentrations than this can be detected when only partial growth of the test organism occurs, such concentrations cannot be accepted as therapeutic levels.

TABLE I

BLOOD PENICILLIN LEVELS FOLLOWING THE INTRAMUSCULAR INJECTION OF 500,000 UNITS IN NORMAL SALINE

\begin{tabular}{c|c|c|c|c|c|c|c}
\hline $\begin{array}{c}\text { Identification } \\
\begin{array}{c}\text { No. of } \\
\text { subject }\end{array}\end{array}$ & \multicolumn{6}{|c}{ Blood levels in u/ml. } \\
\cline { 2 - 6 } & $\begin{array}{c}\frac{1}{2} \\
\text { hr. }\end{array}$ & $\begin{array}{c}3 \\
\text { hrs. }\end{array}$ & $\begin{array}{c}6 \\
\text { hrs. }\end{array}$ & $\begin{array}{c}9 \\
\text { hrs. }\end{array}$ & $\begin{array}{c}12 \\
\text { hrs. }\end{array}$ & $\begin{array}{c}16 \\
\text { hrs. }\end{array}$ & $\begin{array}{c}18 \\
\text { hrs. }\end{array}$ \\
\hline 1 & 4.5 & 2.0 & 0.5 & 0.25 & - & 0.03 & 0 \\
2 & 4.0 & 1.5 & - & - & 0.06 & 0 & 0 \\
3 & 4.0 & 1.0 & - & - & 0.03 & 0 & 0 \\
4 & 4.0 & 0.8 & - & - & 0 & 0 & 0 \\
\hline
\end{tabular}

\section{Results}

Aqueous Penicillin.-Four subjects, all at rest in bed, were given 500,000 units of penicillin in normal saline by intramuscular injection. The blood levels are shown in Table $I$ and Fig. 1.

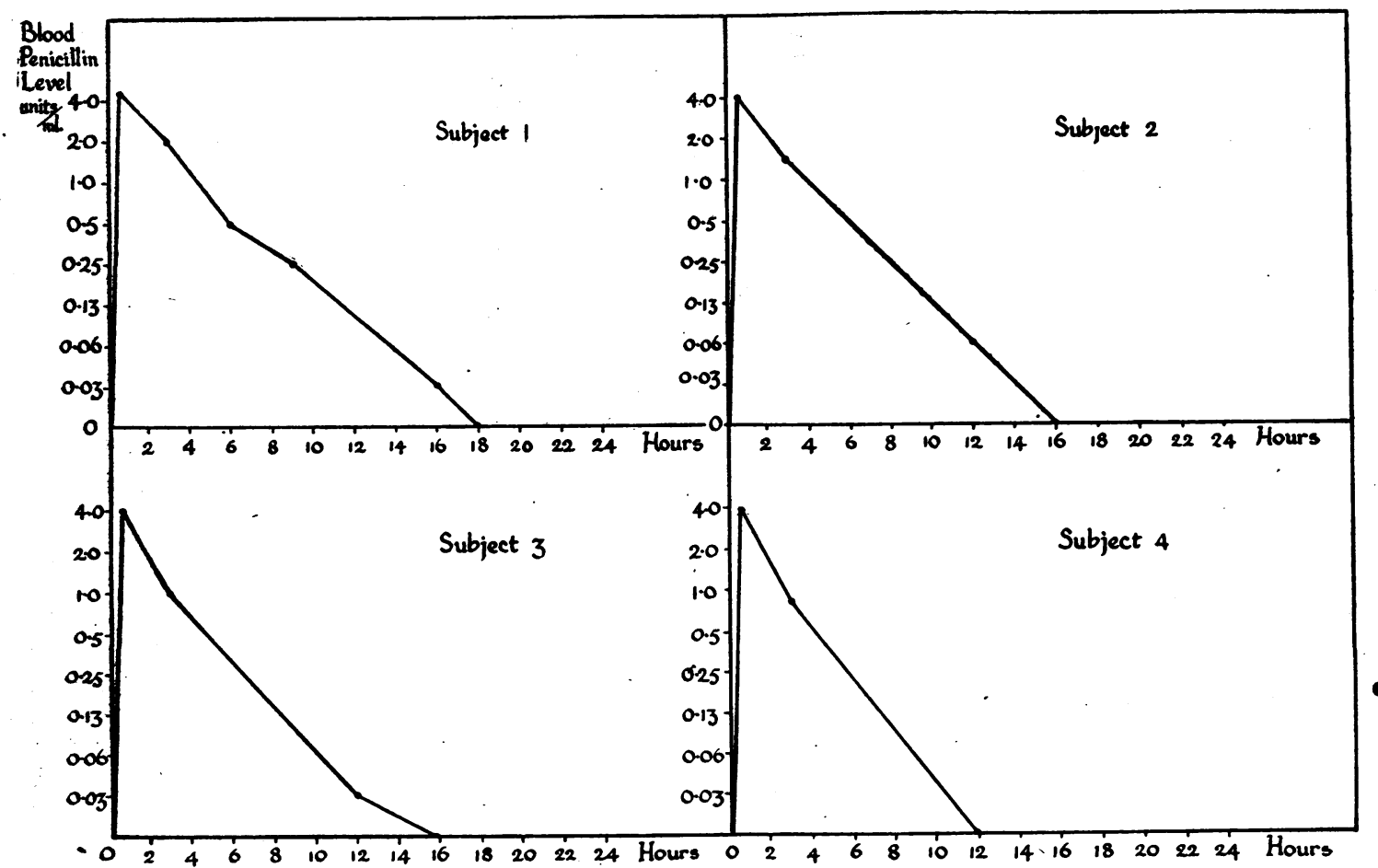

Fio. 1.-Blood levels following 500,000 units penicillin in normal saline intramuscularly. 
TABLE II

PENICILLIN IN ARACHIS OIL AND BEESWAX

\begin{tabular}{|c|c|c|c|c|c|c|c|c|c|c|c|c|}
\hline \multirow{3}{*}{$\begin{array}{l}\text { No. of } \\
\text { subject }\end{array}$} & \multicolumn{2}{|c|}{ Preparation } & \multirow{3}{*}{ Dose $(u)$} & \multirow{3}{*}{$\begin{array}{c}\text { Rest or } \\
\text { ambu- } \\
\text { lant }\end{array}$} & \multirow{2}{*}{\multicolumn{8}{|c|}{ Blood levels in $\mathrm{u} / \mathrm{ml}$. }} \\
\hline & \multirow{2}{*}{$\underset{\%}{\text { Beeswax }}$} & \multirow{2}{*}{$\begin{array}{l}\text { Pen. con- } \\
\text { centration } \\
\text { in } \mathrm{u} / \mathrm{ml} \text {. }\end{array}$} & & & & & & & & & & \\
\hline & & & & & $\frac{1}{2} \mathrm{hr}$. & $3 \mathrm{hrs}$. & $6 \mathrm{hrs}$. & 9 hrs. & $12 \mathrm{hrs}$. & $16 \mathrm{hrs}$ & $20 \mathrm{hrs}$. & $24 \mathrm{hrs}$. \\
\hline $\begin{array}{r}5 \\
6 \\
7 \\
8 \\
9 \\
10 \\
11 \\
12 \\
13 \\
14 \\
15 \\
16 \\
17 \\
18 \\
19\end{array}$ & $\begin{array}{l}4 \cdot 5 \\
4 \cdot 5 \\
4 \cdot 5 \\
4 \cdot 5 \\
4 \cdot 5 \\
4 \cdot 5 \\
4 \cdot 5 \\
4 \cdot 5 \\
4 \cdot 5 \\
4 \cdot 5 \\
4 \cdot 5 \\
4 \cdot 5 \\
4 \cdot 8 \\
4.8 \\
4.8\end{array}$ & $\begin{array}{l}300,000 \\
300,000 \\
300,000 \\
300,000 \\
300,000 \\
300,000 \\
300,000 \\
300,000 \\
300,000 \\
125,000 \\
125,000 \\
125,000 \\
200,000 \\
200,000 \\
300,000\end{array}$ & $\begin{array}{l}600,000 \\
600,000 \\
600,000 \\
300,000 \\
300,000 \\
300,000 \\
300,000 \\
300,000 \\
300,000 \\
500,000 \\
500,000 \\
250,000 \\
500,000 \\
500,000 \\
500,000\end{array}$ & $\begin{array}{l}\mathbf{R} \\
\mathbf{R} \\
\mathbf{R} \\
\mathbf{R} \\
\mathbf{A} \\
\mathbf{A} \\
\mathbf{A} \\
\mathbf{A} \\
\mathbf{A} \\
\mathbf{A} \\
\mathbf{A} \\
\mathbf{A} \\
\mathbf{R} \\
\mathbf{R} \\
\mathbf{R}\end{array}$ & $\begin{array}{l}0.5 \\
1.0 \\
0.5 \\
1.0 \\
= \\
= \\
= \\
= \\
= \\
2.0 \\
0.2 \\
0.75 \\
0.5\end{array}$ & $\begin{array}{l}0.5 \\
1.0 \\
= \\
= \\
= \\
= \\
= \\
= \\
2.0 \\
0.5 \\
2.0 \\
1.0\end{array}$ & $\begin{array}{l}\overline{0.75} \\
= \\
= \\
\overline{0} \\
\overline{ } \\
\overline{1.0} \\
\overline{-} \\
1.0 \\
1.0 \\
2.0\end{array}$ & $\begin{array}{l}0.25 \\
0.75 \\
= \\
= \\
= \\
= \\
= \\
= \\
\bar{Z} \\
0.25 \\
1.0\end{array}$ & $\begin{array}{l}0.2 \\
0.25 \\
= \\
= \\
= \\
= \\
= \\
= \\
= \\
1.0 \\
0.25 \\
0.25\end{array}$ & $\begin{array}{l}0.13 \\
0.25 \\
0.2 \\
0.06 \\
- \\
0.25 \\
= \\
= \\
= \\
= \\
0.25 \\
0.5 \\
0.13 \\
0.75\end{array}$ & $\begin{array}{l}0.13 \\
0.06 \\
0.06 \\
0 \\
0.13 \\
= \\
= \\
= \\
= \\
0 \cdot 13 \\
0 \cdot 1 \\
0.2 \\
0.5\end{array}$ & $\begin{array}{l}0.06 \\
0.02 \\
0.03 \\
0 \\
0.03 \\
0.13 \\
0.03 \\
0.05 \\
0.2 \\
0.03 \\
0.02 \\
0.02 \\
0.13 \\
0.13 \\
0.06\end{array}$ \\
\hline
\end{tabular}

Beeswax and Arachis Oil.-A few experiments with penicillin in beeswax and arachis oil were carried out to check the results with those of Romansky and Rittman and to provide a basis for comparison with the ethyl oleate preparations. These were performed under the same conditions, in the same laboratory, and with the same technique.

Table II shows the preparation used for each subject, the dose, the activity of the patient, and the blood levels obtained. It will be noted that, with one exception (subject 8), all these subjects, regardless of the preparation used and the dose employed, still maintained a detectable amount of penicillin in the blood twenty-four hours after injection. Fig. $2 a$ and $b$ shows the blood level curves for the resting subjects. The arachis oil preparations made by Imperial Chemical Industries gave the results shown in Tables III and IV for resting and ambulant subjects respectively.

\section{TABLE III}

BLOOD LEVELS OBTAINED AFTER 600,000 UNITS I.C.I. PENICILLIN

$(1 \%$ beeswax in arachis oil ; 300,000 units pure penicillin 2(G) per ml.)

\begin{tabular}{cc|c|c|c}
\hline $\begin{array}{c}\text { - } \begin{array}{c}\text { Identification No. } \\
\text { of subject }\end{array} \\
\end{array}$ & \multicolumn{3}{|c}{ Bloed levels (u/ml.) } \\
\cline { 3 - 5 } 93 & $\ldots$ & $\frac{1}{2}$ hr. & 12 hrs. & 16 hrs. \\
\hline 94 & $\ldots$ & 2.5 & 0.06 & 0 \\
95 & $\ldots$ & 2.0 & 0.06 & 0 \\
96 &.. & 2.0 & 0.25 & 0 \\
\hline
\end{tabular}

TABLE IV

BLOOD LEVELS OBTAINED 24 HOURS AFTER 500,000 UNITS I.C.I. PENICILLIN

$(4.5 \%$ beeswax in arachis oil ; $125,000 \mathrm{u} / \mathrm{ml}$.)

\begin{tabular}{c|c}
\hline $\begin{array}{c}\text { Identification } \\
\text { No. of } \\
\text { subject }\end{array}$ & Blood level (u/ml.) \\
\hline 80 & 0 \\
81 & 0.13 \\
82 & 0.06 \\
83 & 0.25 \\
84 & 0 \\
85 & 0.04 \\
86 & 0.03 \\
87 & 0.13 \\
88 & $0 \cdot 13$ \\
89 & 0.04 \\
90 & 0.02 \\
91 & 0.13 \\
92 & \\
\hline
\end{tabular}

Beeswax and Ethyl Oleate.-The blood levels obtained from penicillin in beeswax and ethyl oleate mixtures, together with the preparation used and the dose employed, are shown for resting and ambulant cases respectively in Tables $\mathrm{V}$ and VI. The administration of these preparations was attended by no untoward effects except when the injections were subcutaneous. In these cases the patients complained of pain, the extent of which was experienced by myself in four experiments. In each instance the injection was practically painless, but after approximately six hours a dull ache was noticed which was considerably intensified by movement. This pain was accompanied by a 
variable degree of redness and swelling, but no abscess formation was observed. The symptoms subsided slowly, but complete freedom was not reached for six or seven days. It was felt that symptoms of this sort constituted a barrier to the use of this route of administration in practice, and no further experiments using it were conducted.

\section{Discussion}

Aqueous Penicillin.-The duration of detectable blood levels following the intramuscular injection of 500,000 units of penicillin in aqueous solution (Table I and Fig. 1) provides the standard with which to compare any preparation designed to give prolonged action. Subject 1 showed a slightly longer duration of blood levels than subjects 2 and 3 , but this is offset by the poorer result with subject 4. It would seem that the expected duration of blood levels following this dose is twelve hours for a therapeutic level and sixteen hours for complete disappearance of the penicillin. This is reasonably in accordance with the report of Fleming and others (1944), who showed that 100,000 units gave a therapeutic level for five hours following intramuscular injection. Though larger doses than this were not employed by these workers, one might expect from their results that 500,000 units would give detectable levels for about twelve hours. It is necessary, therefore, that any penicillin preparation, to qualify as one giving prolonged action, should give rise to detectable levels of penicillin in the blood at intervals of more than twelve to sixteen hours after an intramuscular injection of 500,000 units.

Beeswax and Arachis Oil.-All the tests carried out on the standard B.P. preparation of penicillin in beeswax and arachis oil gave detectable blood levels at considerably longer intervals after injection than did aqueous solutions. The results (Table II and Fig. 2) are in agreement with those of Romansky

TABLE V

PENICILLIN IN ETHYL OLEATE AND BEESWAX: RESTING SUBJECTS

\begin{tabular}{|c|c|c|c|c|c|c|c|c|c|c|c|c|}
\hline \multirow{3}{*}{$\begin{array}{l}\text { No. of } \\
\text { subject }\end{array}$} & \multicolumn{2}{|c|}{ Preparation } & \multirow{3}{*}{ Dose (u) } & \multirow{3}{*}{ Route } & \multicolumn{8}{|c|}{ Blood levels in $\mathrm{u} / \mathrm{ml}$. } \\
\hline & \multirow{2}{*}{$\begin{array}{c}\text { Beeswax } \\
\%\end{array}$} & \multirow{2}{*}{$\begin{array}{l}\text { Pen. con- } \\
\text { centration } \\
\text { in } u / m l .\end{array}$} & & & & & & & & & & \\
\hline & & & & & $\frac{1}{2} \mathrm{hr}$. & 3 hrs. & $6 \mathrm{hrs}$. & 9 hrs. & $12 \mathrm{hrs}$ & $16 \mathrm{hrs}$ & $20 \mathrm{hrs}$ & $24 \mathrm{hrs}$ \\
\hline 20 & $4 \cdot 0$ & 125,000 & 500,000 & IM & $4 \cdot 0$ & $2 \cdot 0$ & 0.75 & 0.5 & 0.06 & 0 & 0 & 0 \\
\hline 21 & 4.0 & 125,000 & 500,000 & IM & $4 \cdot 0$ & 1.0 & 0.1 & $0 \cdot 1$ & & 0 & 0 & 0 \\
\hline 22 & $4 \cdot 0$ & 125,000 & 500,000 & IM & $4 \cdot 0$ & 1.0 & 0.06 & 0.06 & 0 & 0 & 0 & 0 \\
\hline 23 & $4 \cdot 0$ & 125,000 & 500,000 & SC & 0.5 & 1.0 & 0.35 & $0 \cdot 2$ & $0 \cdot 1$ & 0.06 & 0.03 & $\mathbf{0}$ \\
\hline 24 & $4 \cdot 8$ & 200,000 & 500,000 & IM & 0.5 & 1.0 & 1.0 & $0 \cdot 25$ & $0 \cdot 13$ & 0.06 & 0.06 & 0 \\
\hline 25 & $4 \cdot 8$ & 200,000 & 500,000 & IM & 1.0 & $2 \cdot 0$ & $4 \cdot 0$ & 0.06 & 0 & & 0 & 0 \\
\hline 26 & $4 \cdot 8$ & 200,000 & 500,000 & IM & 0.5 & $2 \cdot 0$ & 0.5 & 0.13 & 0.03 & 0 & 0 & 0 \\
\hline 27 & $4 \cdot 8$ & 200,000 & 500,000 & IM & 0.25 & 0.75 & 0.25 & 0.5 & 0.25 & $0 \cdot 13$ & $0 \cdot 13$ & $0 \cdot 13$ \\
\hline 28 & $4 \cdot 8$ & 200,000 & 500,000 & SC & 0.5 & 1.0 & 0.75 & 0.5 & 0.35 & 0.13 & 0.25 & 0 \\
\hline 29 & $4 \cdot 8$ & 200,000 & 500,000 & SC & 1.0 & 1.0 & 1.0 & 0.25 & $0 \cdot 2$ & 0.13 & - & 0.01 \\
\hline 30 & $4 \cdot 8$ & 200,000 & 500,000 & SC & 0.35 & $1 \cdot 5$ & 1.0 & 0.35 & 0.35 & 0.13 & 0.05 & 0.01 \\
\hline 31 & $4 \cdot 8$ & 200,000 & 250,000 & SC & 0.0 & 0.5 & 0.25 & $0 \cdot 1$ & 0.03 & & & 0 \\
\hline 32 & $4 \cdot 8$ & 300,000 & 600,000 & IM & $2 \cdot 0$ & - & - & - & 0.5 & $0 \cdot 13$ & 0.06 & - \\
\hline 33 & $4 \cdot 8$ & 300,000 & 600,000 & IM & $4 \cdot 0$ & $\ldots$ & - & - & 0.13 & 0.03 & & 0 \\
\hline 34 & $4 \cdot 8$ & 300,000 & 600,000 & IM & $8 \cdot 0$ & - & - & - & 0.25 & 0.06 & 0.05 & 0.01 \\
\hline 35 & $4 \cdot 8$ & 300,000 & 600,000 & IM & 3.0 & - & - & - & $0 \cdot 1$ & 0.03 & & 0 \\
\hline 36 & $4 \cdot 8$ & 300,000 & 600,000 & IM & $2 \cdot 0$ & - & $\ldots$ & $\ldots$ & - & 0.1 & 0.05 & 0.01 \\
\hline 37 & 6.0 & 100,000 & 300,000 & IM & 1.0 & 0.5 & 0.25 & 0.06 & 0.04 & - & - & 0 \\
\hline 38 & 6.0 & 100,000 & 300,000 & IM & 0.75 & 1.0 & 0.25 & 0.13 & 0.04 & 0.03 & 一 & 0 \\
\hline 39 & 6 & 100,000 & 300,000 & IM & 0.3 & 0.5 & 0.25 & 0.1 & 0.06 & - & - & 0.03 \\
\hline 40 & 6.0 & 100,000 & 500,000 & IM & 0.5 & 0.75 & 0.25 & - & $0 \cdot 2$ & $0 \cdot 13$ & 0.07 & 0.06 \\
\hline 41 & 6.0 & 100,000 & 500,000 & IM & $2 \cdot 0$ & 1.0 & 0.5 & - & 0.06 & 0.05 & 0.05 & 0.06 \\
\hline 42 & 6.0 & 125,000 & 500,000 & IM & $3 \cdot 0$ & $4 \cdot 0$ & $1 \cdot 0$ & - & 0.3 & - & 0.06 & 0.04 \\
\hline 43 & $6 \cdot 0$ & 125,000 & 500,000 & IM & 1.5 & $1 \cdot 5$ & 1.0 & - & 0.25 & - & 0.05 & 0 \\
\hline 44 & 6.0 & 200,000 & 500,000 & IM & 0 & 0.5 & 0.25 & $0 \cdot 13$ & 0.03 & $0 \cdot 2$ & 0 & 0 \\
\hline 45 & 6.0 & 200,000 & 500,000 & IM & 0.5 & 0.75 & 0.3 & $0 \cdot 1$ & & 0 & 0 & 0 \\
\hline 46 & 6.0 & 200,000 & 500,000 & SC & 0.25 & 0.5 & 0.25 & $0 \cdot 25$ & 0.25 & 0.13 & 0.13 & 0 \\
\hline 47 & $6 \cdot 0$ & 200,000 & 500,000 & SC & 0.75 & 0.25 & 0.25 & $0 \cdot 13$ & 0.06 & 0.05 & 0.03 & 0 \\
\hline 48 & & 300,000 & 500,000 & IM & 0.25 & 0.75 & $0 \cdot 3$ & $0 \cdot 13$ & 0.13 & $0 \cdot 1$ & 0.06 & 0.04 \\
\hline 49 & & 300,000 & 500,000 & IM & $2 \cdot 0$ & $2 \cdot 0$ & 1.0 & 0.5 & 0.25 & 0.2 & 0.13 & 0.06 \\
\hline 50 & & 300,000 & 500,000 & IM & 4 & 0.5 & $0 \cdot 13$ & 0.03 & 0 & & 0 & 0 \\
\hline 51 & & 300,000 & 500,000 & IM & & 0.5 & - & $0 \cdot 13$ & 0.06 & 0.03 & 0 & 0 \\
\hline
\end{tabular}




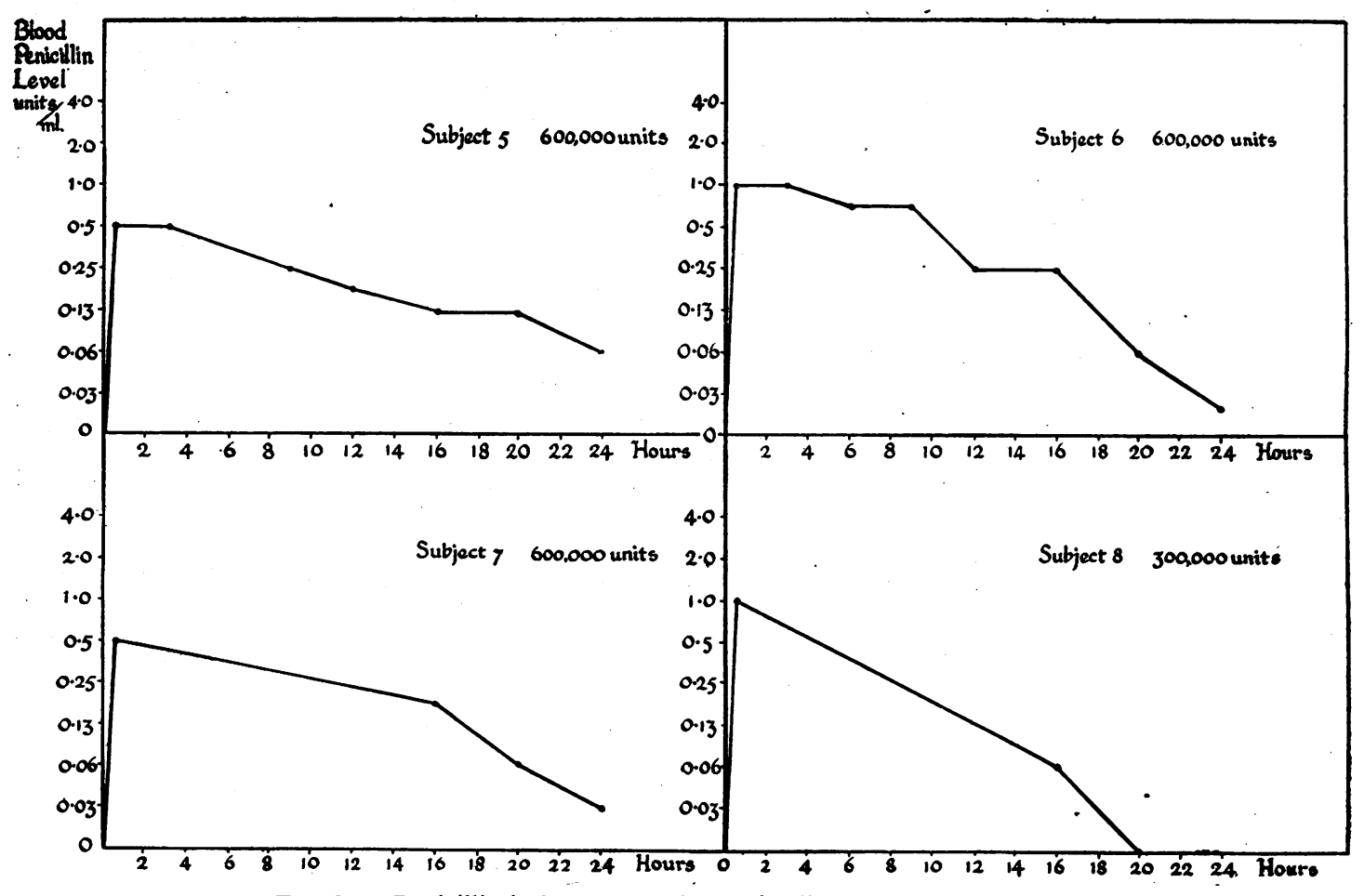

FIG. 2A.-Penicillin in beeswax and arachis oil-four resting subjects.

(1945) though they are rather better than those reported by Kirby and others (1945). The latter authors found that in 69 per cent. of their cases blood levels were detectable for not more than twelve hours following an intramuscular injection of 300,000 units, only about. 6 per cent. showing levels twenty-four hours after the injection. In the present series, however, out of six cases given 300,000 units, only one (subject 8) failed to show penicillin in the blood at twenty hours, while the remainder still had substantial amounts at twentyfour. It is interesting to note that subject 16 still showed a detectable amount of penicillin in the blood twenty-four hours after only 250,000 units. In this connexion Table II shows that the size of the dose appears to be relatively unimportant in determining the duration of the blood levels, for in many cases 300,000 units gave results as good as or better than 500,000 or 600,000 units. In addition, the activity of the patient seems to be of no consequence.

I.C.I. Preparations.-The first of the I.C.I. preparations, containing 1 per cent. beeswax and 300,000 units of pure penicillin $2(\mathrm{G})$ per $\mathrm{ml}$., was tested only in resting subjects. Four experiments (Table III) showed that in no case could penicillin be detected in the blood for more than twelve hours from the time of the injection. This is no better than the expected duration of blood levels following the administration of penicillin in aqueous solution.

The second preparation, containing 4.5 per cent. beeswax and 125,000 units of commercial penicillin per ml., was tested in ambulant subjects. Table IV shows that the duration of detectable blood levels in 60 per cent. of these cases was as long as that obtained with the B.P. preparation. This is, of course, an exceedingly satisfactory finding, for this mixture, as already pointed out, has the advantage over the standard preparations of being fluid and so more easily manipulated.

Ethyl Oleate Preparations.-The most striking feature shown by the ethyl oleate preparations (Table V) was the extreme variation of response in different individuals. This variation was present with all the preparations tested, regardless of the amount of beeswax or the penicillin concentration. For example, subject 27 showed 0.13 unit of penicillin per ml. of serum twenty-four hours after an intramuscular injection of 500,000 units of penicillin in 4.8 per cent. beeswax in ethyl oleate. But an equal dose of the same preparation gave detectable levels for only twelve hours in subject 26 . Similarly, 


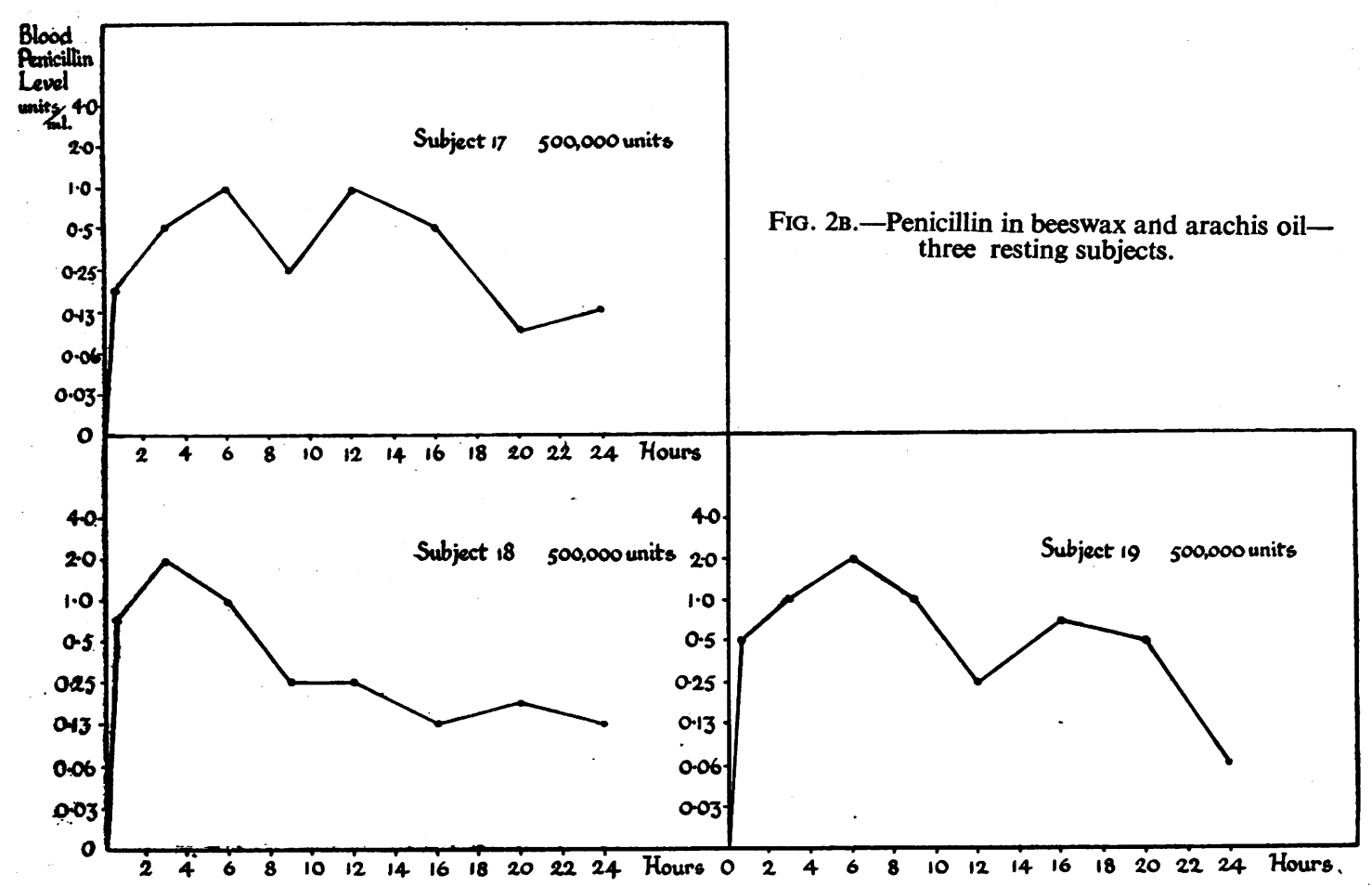

with 6 per cent. beeswax, subject 49 showed 0.06 $\mathrm{u} / \mathrm{ml}$. twenty-four hours after injection, while in subject $\mathbf{5 0}$ the penicillin had disappeared from the blood in twelve hours.

When the subcutaneous route was employed for injections the variation was much less marked. Subjects 23, 28, 29, 30, 46 and 47 all gave detectable blood levels at eighteen to twenty-four hours after 500,000 units of penicillin, regardless of the preparation used. But, as previously noted, this method of administration had to be abandoned owing to the protonged pain and discomfort produced.

The amount of beeswax employed in the preparation between the limits tested of 4 per cent. to 6 per cent. does not appear to be of very great importance, though broadly speaking it may be said that the prolongation of detectable blood levels tends to increase with increasing beeswax concentration. Thus with mixtures containing six per cent. of beeswax, 50 per cent. of subjects still showed penicillin in the blood twenty-four hours after injection ; with 4.8 per cent. beeswax, 33 per cent. gave a blood level at twenty-four hours, and with 4 per cent. beeswax (Table VI) 29 per cent. gave a detectable level at twenty-four hours.

The concentration of penicillin in the beeswaxethyl oleate mixtures tested seemed to be of little importance as regards the blood levels produced, but of course the bulk of the injection for a given dose decreases with increasing concentration of penicillin. This is of considerable importance, since with large amounts of oily preparations there may be a tendency to produce lasting tissue nodules, and in any case a large injection produces more discomfort than a small one. The difficulty is exemplified by a preparation containing 6 per cent. of beeswax and only 50,000 units of penicillin per $\mathrm{ml}$. It was only practicable to employ doses of 250,000 units $(5 \mathrm{ml}$.) of this preparation, and in no case (subjects 73 to 78 inclusive, Table VI) were blood levels detectable twenty-four hours after injection. At the other extreme, excessively high concentrations of penicillin cause the preparation to become too viscid, and incidentally with no increase in the duration of blood levels. About $200,000 \mathrm{u} / \mathrm{ml}$. appears to be a satisfactory compromise.

Resting and Ambulant Patients. - No appreciable difference in the duration or height of the blood levels was observed between resting and ambulant subjects, though such a comparison could be made only on the twenty-four hour blood specimens, on account of the difficulty in obtaining frequent specimens from out patients. As has been men- 
tioned previously, Table II shows that with beeswaxarachis oil mixtures blood levels are nearly always detectable twenty-four hours after a dose of 300,000 units or more, whether the subject is at rest or ambulant. In the case of beeswax-ethyl oleate preparations Table VI shows that penicillin was detectable in the blood twenty-four hours after injection in five out of eighteen ambulant subjects, each of whom received an intramuscular dose of 500,000 units of penicillin in 4 per cent. beeswax in ethyl oleate. In three resting subjects (Nos. 20, 21, and 22, Table V) no blood levels were detected after twelve hours in one instance and nine hours in the other two. Though the latter group is too small to be of any real significance, it is nevertheless unlikely, from these results, that the rate of absorption, and consequently excretion, is increased to any appreciable extent by minor degrees of exercise.

In conclusion it is interesting to speculate whether, in view of the reduced cost of penicillin, it may become practicable in the future to substitute large doses of penicillin in aqueous solution for the oily preparations. As shown in Table I, aqueous penicillin can be expected to produce blood levels for twelve hours after an intramuscular injection of 500,000 units, and it may be that larger doses given once a day would produce adequate blood concentrations for twenty-four hours.

\section{Summary}

1. Penicillin in beeswax-ethyl oleate mixtures frequently gives rise to more prolonged blood levels than an equal dose of penicillin in aqueous solution. The duration of detectable blood levels, however, is rarely as great as that produced by beeswax-arachis oil preparations.

2. Marked individual variation was encountered in the duration and height of blood levels produced by beeswax-ethyl oleate preparations.

3. The percentage of beeswax in the ethyl oleate between 4 per cent: and 6 per cent. w/v, does not greatly affect the duration of blood levels, though, on the whole, the more beeswax present the longer the duration.

4. The concentration of penicillin is of importance in connection with the bulk of the material to be

TABLE VI

PENICILLIN IN ETHYL OLEATE AND BEESWAX : AMBULANT SUBJECTS

\begin{tabular}{|c|c|c|c|c|c|c|c|c|c|}
\hline \multirow{3}{*}{$\begin{array}{l}\text { No. of } \\
\text { subject }\end{array}$} & \multicolumn{2}{|c|}{ Preparation } & \multirow{3}{*}{ Dose $(u)$} & \multirow{3}{*}{ Route } & \multirow{2}{*}{\multicolumn{5}{|c|}{ Blood levels in $\mathrm{u} / \mathrm{ml}$. }} \\
\hline & \multirow{2}{*}{$\underset{\%}{\text { Beeswax }}$} & \multirow{2}{*}{$\begin{array}{l}\text { Pen. con- } \\
\text { centration } \\
\text { in } \mathrm{u} / \mathrm{ml} \text {. }\end{array}$} & & & & & & & \\
\hline & & & & & $\frac{1}{2} \mathrm{hr}$. & $6 \mathrm{hrs}$. & $12 \mathrm{hrs}$. & 20 hrs. & 24 hrs. \\
\hline $\begin{array}{l}52 \\
53 \\
54 \\
55 \\
56 \\
57 \\
58 \\
59 \\
60 \\
61 \\
62 \\
63 \\
64 \\
65 \\
66 \\
67 \\
68 \\
69 \\
70 \\
71 \\
72 \\
73 \\
74 \\
75 \\
76 \\
77 \\
78 \\
79\end{array}$ & $\begin{array}{l}4 \cdot 0 \\
6 \cdot 0 \\
4 \cdot 0 \\
4 \cdot 0 \\
4 \cdot 0 \\
4 \cdot 0 \\
4 \cdot 0 \\
4 \cdot 0 \\
4 \cdot 0 \\
4 \cdot 0 \\
4 \cdot 0 \\
4 \cdot 0 \\
4 \cdot 0 \\
4 \cdot 0 \\
4 \cdot 0 \\
4 \cdot 0 \\
4 \cdot 0 \\
4 \cdot 0 \\
4 \cdot 0 \\
4 \cdot 8 \\
4 \cdot 8 \\
6 \cdot 0 \\
6 \cdot 0 \\
6 \cdot 0 \\
6 \cdot 0 \\
6 \cdot 0 \\
6 \cdot 0 \\
6 \cdot 0\end{array}$ & $\begin{array}{l}125,000 \\
125,000 \\
125,000 \\
125,000 \\
125,000 \\
125,000 \\
125,000 \\
125,000 \\
125,000 \\
125,000 \\
125,000 \\
125,000 \\
125,000 \\
125,000 \\
125,000 \\
125,000 \\
125,000 \\
125,000 \\
125,000 \\
300,000 \\
300,000 \\
500,000 \\
500,000 \\
500,000 \\
500,000 \\
500,000 \\
500,000 \\
250,000\end{array}$ & $\begin{array}{l}500,000 \\
500,000 \\
500,000 \\
500,000 \\
500,000 \\
500,000 \\
500,000 \\
500,000 \\
500,000 \\
550,000 \\
500,000 \\
500,000 \\
500,000 \\
500,000 \\
500,000 \\
500,000 \\
500,000 \\
500,000 \\
400,000 \\
600,000 \\
500,000 \\
250,000 \\
250,000 \\
250,000 \\
250,000 \\
250,000 \\
250,000 \\
500,000\end{array}$ & $\begin{array}{l}\text { IM } \\
\text { IM } \\
\text { IM } \\
\text { IM } \\
\text { IM } \\
\text { IM } \\
\text { IM } \\
\text { IM } \\
\text { IM } \\
\text { IM } \\
\text { IM } \\
\text { IM } \\
\text { IM } \\
\text { IM } \\
\text { IM } \\
\text { IM } \\
\text { IM } \\
\text { IM } \\
\text { SC } \\
\text { IM } \\
\text { SC } \\
\text { IM } \\
\text { IM } \\
\text { IM } \\
\text { IM } \\
\text { IM } \\
\text { IM } \\
\text { IM }\end{array}$ & $\begin{array}{l}= \\
= \\
= \\
= \\
= \\
= \\
= \\
= \\
= \\
2 \cdot 0 \\
2 \cdot 0 \\
= \\
= \\
= \\
=\end{array}$ & $\begin{array}{l}0.25 \\
1.0 \\
= \\
= \\
= \\
= \\
= \\
= \\
= \\
= \\
= \\
= \\
\bar{Z} \\
0.75 \\
0.5 \\
0.3 \\
0.13 \\
0.13 \\
0.06 \\
0.25 \\
0 \\
= \\
-\end{array}$ & $\begin{array}{l}= \\
= \\
= \\
= \\
= \\
= \\
= \\
= \\
= \\
= \\
0 \cdot 04 \\
0 \cdot 06 \\
= \\
= \\
= \\
=\end{array}$ & $\begin{array}{l}= \\
= \\
= \\
= \\
= \\
= \\
= \\
= \\
= \\
= \\
0 \\
0 \\
= \\
\overline{=} \\
\overline{=} \\
0.13\end{array}$ & $\begin{array}{l}0 \\
0 \\
0.02 \\
0 \cdot 13 \\
0 \\
0 \\
0.03 \\
0 \\
0 \\
0 \\
0 \\
0 \\
0 \\
0.04 \\
0.03 \\
0 \\
0 \\
0 \\
0 \\
0 \\
0 \\
0 \\
0 \\
0 \\
0 \\
0 \\
0\end{array}$ \\
\hline
\end{tabular}


injected. About $200,000 \mathrm{u} / \mathrm{ml}$. seems to be a reasonable amount. The penicillin concentration has little effect on the duration of blood levels.

5. Subcutaneous injection of beeswax-ethyl oleate preparations tends to give more prolonged and less variable blood levels than the intramuscular route, but unfortunately the former route is accompanied by considerable pain and swelling which persist for some days.

6. The duration of blood levels is uninfluenced by minor degrees of exercise.

7. A preparation of Imperial Chemical Industries Limited containing 4.5 per cent. beeswax in arachis oil is fluid at room temperature and gives results almost as good as those of the standard B.P. preparation.
This work was carried out on behalf of the Ministry of Health. I should like to express my gratitude to Sir Alexander Fleming for his invaluable advice and encouragement and to Dr. McElligott and various members of the staff of the Venereal Diseases Department and the Penicillin Unit for their co-operation in obtaining the blood specimens.

\section{REFERENCES}

Fleming, A., and Smith, C. (1947). Lancet, 1, 401.

Fleming, A., Young, M. Y., Suchet, J., and Rowe, A. J. E. (1944). Ibid., 2, 621 .

Kirby, W. M. M., Leifer, W., Martin, S. P., Rammelkamp, C. H., and Kinsman, J. M. (1945). J. Amer. med. Ass., 129, 940.

Romansky, M. J., and Rittman, G. E. (1944). Science, 100, 196 .

—_, - -(1945). New Engl. J. Med., 233, 577. 